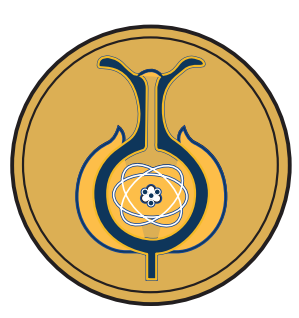

\title{
Effect of two cytokinins and a growth inhibitor on the in vitro tuberization of two genotypes of Solanum tuberosum L. crs. Atlantic and Alpha
}

Efecto de dos citocininas y un inhibidor del crecimiento en la tuberización in vitro de dos genotipos de Solanum tuberosum L. vars. Atlantic y Alpha Efeito de duas citocininas e um inibidor do crescimento na tuberização in vitro de dos genótipos de Solanum tuberosum L. vars. Atlantic e Alfa

José Antonio García-García dendrogar@yahoo.com

Laboratorio de Cultivo de Tejidos Vegetales,

Escuela de Ciencias Agrarias, Universidad Nacional Heredia, Costa Rica.

Orcid: https://orcid.org/0000-0003-2015-8932

\section{José Bernal Azofeifa-Bolaños} jb12azo@gmail.com

Instituto de Investigación y Servicios Forestales, Universidad Nacional Heredia, Costa Rica.

Orcid: https://orcid.org/0000-0002-8902-0352
Frank Solano-Campos

frank.solano.campos@una.cr Laboratorio de Biotecnología de Plantas,

Escuela de Ciencias Biológicas

Universidad Nacional

Heredia, Costa Rica.

Orcid: https://orcid.org/0000-0003-1055-9070

\section{Rafael Orozco-Rodríguez}

rafael.orozco.rodriguez@una.cr

Laboratorio de Cultivo de Tejidos Vegetales,

Escuela de Ciencias Agrarias,

Universidad Nacional

Heredia, Costa Rica.

Orcid: https://orcid.org/0000-0003-0917-2442

Recibido-Received: 5/abr/2018 • Corregido-Corrected: 4/jun/2018.

Aceptado-Accepted: 19/ago/2018 • Publicado-Published: 31/jul/2019.

\section{Abstract}

This investigation was carried out to evaluate the effect of two cytokinins: 6-benzilaminopurine (BAP) (6.5 $\left.\mathrm{mg}^{\left.\right|^{-1}}\right)$ and kinetin $(\mathrm{K})\left(2.5 \mathrm{mg} \mathrm{|}^{-1}\right)$, as well as the growth inhibitor abscisic acid (ABA) $\left(1.0 \mathrm{mg} \mathrm{|}^{-1}\right)$ on the in vitro tuberization capacity of two potato varieties: Atlantic and Alpha. The basal culture medium MS (1962) was used as a control. The responses were different between varieties. In cv. Atlantic, the analysis of the number (NM), weight (WM) and diameter (DM) of microtubers indicated that the addition of growth regulators did not affect induction and development of microtubers. However, when BAP was used, a nonsignificant increment of $41 \%$ was observed in the number of the microtubers compared to the control treatment, from 2.6 to 4.4 . The addition of cytokinins and ABA to the medium did not have a significant impact on the development of microtubers. In cv. Alpha the cytokinins used without ABA increased the number of microtubers, which were larger and heavier than those of the control treatment. In this variety, ABA significantly reduced the values of the NM, WM and DM variables. The exogenous action of cytokinins in the culture medium is likely to have caused an endogenous hormonal imbalance in the Atlantic and 
Alpha genotypes which interfered with their innate microtuberization ability, a result that was even more evident for cv. Alpha, which showed the need to continue optimizing protocols of genotype-specific systems in potato tissue culture to increase yield and seed quality.

Key words: microtuberization; potato; Solanum tuberosum L; growth regulators.

\section{Resumen}

La presente investigación se llevó a cabo con el objetivo de evaluar el efecto de dos citocininas 6-benzilaminopurina (BAP) $\left(6.5 \mathrm{mg} \mathrm{l}^{-1}\right)$ y kinetina $(\mathrm{K})\left(2.5 \mathrm{mg} \mathrm{l}^{-1}\right)$, más un inhibidor de crecimiento ácido abscísico (ABA) $\left(1.0 \mathrm{mg}^{\mathrm{I}^{-1}}\right)$ sobre la capacidad de tuberización in vitro de dos variedades de papa, Atlantic y Alfa. El medio de cultivo usado como testigo fue el básico MS (1962) sin reguladores del crecimiento. Los resultados obtenidos evidenciaron una respuesta diferente entre variedades. En la variedad Atlantic, el análisis de los datos en relación con las variables número (NM), peso (PM) y diámetro (DM) de microtubérculos indicó que la adición de reguladores de crecimiento no afectó favorablemente la inducción y el desarrollo de microtubérculos, con respecto al testigo. Al utilizar BAP, se notó un incremento no significativo de $41 \%$ en el número promedio de microtubérculos en comparación con el tratamiento control, pasando de 2.6 a 4.4. La adición de citocininas y ABA al medio no provocó efectos positivos en el desarrollo de los microtubérculos. En la variedad Alfa, la utilización de citocininas en ausencia de ABA estimuló el NM y estos fueron más pesados y de mayor diámetro que en el tratamiento testigo. En esta variedad, el ABA causó un efecto negativo en el NM, así como en las variables PM y DM. Probablemente la acción exógena de las citocininas en los medios de cultivo ocasionó un desbalance hormonal endógeno en los genotipos Atlantic y Alfa, que interfirió sobre la capacidad innata de microtuberización, resultado que se evidenció en mayor magnitud para la variedad Alfa, lo cual reveló la necesidad de continuar optimizando los protocolos genotipo-específicos de los sistemas de cultivo de tejidos en papa para aumentar el rendimiento y la calidad de la semilla.

Palabras clave: microtuberización; papa; Solanum tuberosum L.; reguladores de crecimiento.

\section{Resumo}

Apresentepesquisafoilevadaacabocomoobjetivodeavaliaroefeito deduascitocininas6-benzilaminopurina (BAP) (6.5 mg l-1) e quitina (K) (2.5 $\mathrm{mg} \mathrm{l-1}^{-1}$ ), mais um inibidor de crescimento ácido abscísico (ABA) (1.0 mg $\left.\left.\right|^{-1}\right)$ sobre a capacidade de tuberização in vitro de duas variedades de batata, Atlantic e Alfa. 0 meio de cultivo usado como testemunha foi o básico MS (1962) sem reguladores do crescimento. Os resultados obtidos evidenciaram uma resposta diferente entre variedades. Na variedade Atlantic, a análise dos dados com relação às variáveis número (NM), peso (PM) e diâmetro (DM) de microtubérculos indicou que a adição de reguladores de crescimento não afetou favoravelmente a indução e o desenvolvimento de microtubérculos, com relação à testemunha. Ao utilizar BAP, notou-se um aumento não significativo de $41 \%$ no número médio de microtubérculos em comparação com o tratamento controle, passando de 2.6 a 4.4. A adição de citocininas e $A B A$ ao meio não provocou efeitos positivos no desenvolvimento dos microtubérculos. $\mathrm{Na}$ variedade Alfa, a utilização de citocininas na ausência de ABA estimulou o NM e estes foram mais pesados e de maior diâmetro do que no tratamento testemunha. Nesta variedade, 0 ABA causou um efeito negativo no NM, como também nas variáveis PM e DM. Provavelmente a ação exógena das citocininas nos meios de cultivo ocasionou um desequilíbrio hormonal endógeno nos genótipos Atlantic e Alfa, interferindo sobre a capacidade inata de microtuberização, resultado que se evidenciou em maior magnitude para a variedade 
Alfa, revelando a necessidade de continuar na otimização dos protocolos genótipo-específicos dos sistemas de cultivo de tecidos em batata para aumentar o rendimento e a qualidade da semente.

Palavras-chaves: microtuberização; batata; Solanum tuberosum L.; reguladores de crescimento.

T The importance of potatoes as a food crop lies in their ability to form tubers that are high in starch, proteins, antioxidants, vitamins (Shan et al., 2013), as well as minerals and the essential amino acids methionine and cysteine (Abelenda, Navarro, \& Prat, 2011). For these reasons, potatoes have become the fourth most important food crop in the world (Aksenova, Konstantinova, Golyanovskaya, Sergeeva, \& Romanov, 2012; Shan et al., 2013; Yu et al., 2012).

Their propagation takes place primarily asexually, through tubers and microtubers (Al-safadi, Ayyoubi, \& Jawdat, 2000; Li et al., 2005; Zhang, Li, Zhou, Takeuchi, \& Yoneyama, 2006). However, there are two principal problems associated with the production of potato seed in a conventional manner: (1) the low rate of multiplication in the field and (2) the high susceptibility of potatoes to viral, bacterial and fungal diseases (Dobránszki, Magyar-Tábori, \& Hudák, 2008). Therefore, in vitro propagation has become the most viable alternative for ensuring efficient multiplication, and supplying the quantity and quality of disease-free plant material which is required for the establishment of large-scale plantations (Dobránszki et al., 2008; Zhang, Zhou, \& $\mathrm{Li}, 2005 \mathrm{~b}$ ), decreasing the high incidence of diseases throughout the year, as well as the high production costs associated with pathogen-tested, certified seed (Sharma, Venkatasalam, \& Singh, 2011a).

The main characteristics of microtubers produced through the in vitro culture technique include the production of disease-free and high-quality seeds, whose greater robustness and ease of use make them suitable explants for automated propagation systems (Motallebi-Azar, Kazemiani, \& Yarmohamadi, 2013). Similarly, they facilitate the maintenance and exchange of genetic material, given that small samples can be stored and subsequently shipped (virus-free) in aseptic conditions, even to countries with strict phytosanitary regulations (Dobránszki et al., 2008; López-Delgado, Sánchez-Rojo, Mora-Herrera, \& Martínez-Gutierrez, 2012). They are also experimental research tools for the study of plant metabolism, evaluation and selection of germplasm, transformation, somatic hybridization, and in vitro selection for traits of agronomic importance such as maturity and tolerance to abiotic stress, among others (Dobránszki et al., 2008).

Microtubers may be used in greenhouses to produce mini-tubers, or grown directly in the field. Those used for direct sowing have a high commercial potential, especially in regions with warm, well-drained soil during the planting season (Park et al., 2009). Furthermore, the yields of some varieties of microtubers are similar to those of conventional seed tubers (Kawakami, Iwama, Jitsuyama, \& Zheng, 2004).

Many factors affect the induction and formation of microtubers. Among these, growth regulators (GR), which play a significant part in this process, have been extensively studied. Consequently, several authors attribute an important role in 
this process to the use of cytokinins such as benzylaminopurine (BAP) (Coleman \& Coleman, 2000; Donnelly, Coleman, \& Coleman, 2003; Lê, 1999; Sarkar, Pandey, \& Sharma, 2006; Zhang et al., 2005b), and kinetin (K) (Aksenova et al., 2005; Aksenova, Konstantinova, Lozhnikova, Golyanovskaya, \& Sergeeva, 2009; Coleman, Donnelly, \& Coleman, 2001; Kefi, Pavlista, Meagher, \& Read, 2000; Romanov et al., 2000), as well as the synergistic effect between them (Al-safadi et al., 2000). Although many plant hormones are assumed to be involved in the regulation of the tuberization, such as those mentioned previously, their effects finally depend on the gibberellin content of tissues (Xu, van Lammeren, Vermeer, \& Vreugdenhil, 1998). However, potato microtuberization is influenced by multiple factors, including genotype, explant type, media, and particular growth conditions (sucrose, light, temperature) (Li et al., 2005).

While the factors mentioned above are well known, little information is available about the effects of physiological age (PA) of the mother tubers on in vitro tuberization. Together with photoperiod, temperature, irradiance and nitrogen fertilization, PA acts directly and indirectly on the tuberization process, promoting changes in hormone concentrations (Villafranca, Veramendi, Sota, \& Mingo-Castel, 1998). For example, earlier and higher microtuberization rates were achieved using single nodal segments of physiologically older source tubers.

Other types of substances analyzed in various studies include abscisic acid (ABA), a growth inhibitor, which is involved in the potato's microtuberization ability as a growth retardant of gibberellin biosynthesis (Macháčková et al., 1998; Xu et al., 1998). While some studies indicate an increased microtuberization using $\mathrm{ABA}(\mathrm{Xu}$ et al., 1998), others argue for an adverse effect of exogenous supply of ABA to the culture medium (Gopal, Chamail, \& Sarkar, 2004), highlighting the importance of maintaining an adequate ratio of cytokinin/ABA, mainly BAP, to counteract the adverse effects of ABA. Thus, the role of cytokinins and $\mathrm{ABA}$ is currently a controversial issue; for example, Gopal et al., (2004) suggests that despite the years spent in this research, there is still a limited understanding of the processes involved in tuberization.

The potential of in vitro culture to obtain high genetic purity and phytosanitary asexual seed motivated us to conduct this research, seeking to determine the effect of two cytokinins (BAP, K) and a growth inhibitor (ABA) on the microtuberization capacity of two potato genotypes under diffuse light conditions. To date, there are no conclusive studies of the microtuberization process in these two genotypes using either single or multiple interacting growth regulators.

\section{Methodology}

\section{Plant material}

The biological material used at the beginning of the investigation consisted of virus-free mini-tubers of the potato varieties Alpha and Atlantic, which had begun to sprout in the dark.

\section{Establishment of axenic cultures}

Single nodal cuttings $(0.5-1.0 \mathrm{~cm}$ long $)$ from etiolated sprouts were disinfected with sodium hypochlorite $3.5 \%(\mathrm{v} / \mathrm{v})$ for $15 \mathrm{mi}$ nutes, and were then rinsed three times with sterile distilled water, and cultured aseptica1ly in Murashige and Skoog (MS) basal medium (Murashige \& Skoog, 1962) in a laminar flow chamber. Each $120 \mathrm{ml}$ culture flask 
contained $20 \mathrm{ml}$ of MS semisolid basal medium with $3 \%$ sucrose. The $\mathrm{pH}$ of the culture medium was adjusted to 5.7 with $1 \mathrm{~N} \mathrm{NaOH}$ before autoclaving at $121^{\circ} \mathrm{C}$ and a pressure of $1.03 \mathrm{~kg} / \mathrm{cm}^{2}$ for 20 minutes.

\section{Microtuberization}

Apical and axillary buds of axenic plantlets were subcultured aseptically and incubated under five treatments in order to evaluate the effects of cytokinins and the growth inhibitor on microtuberization (Table 1).

The vials were transferred to a growth room with a $16 \mathrm{~h} /$ day photoperiod (provided by $75 \mathrm{~W}$ (400-700 nm) daylight fluorescent lamps. To achieve diffuse light conditions $\left(5.7 \mu \mathrm{E} \mathrm{m}^{-2} \mathrm{~s}^{-1}\right)$, the culture flasks were placed in a section of the shelves with indirect lighting. The temperature in the growth room varied between 23 and $25^{\circ} \mathrm{C}$.

\section{Experimental design}

The treatments were conducted in a completely randomized experimental design. Six culture flasks were used per treatment and four explants per flask corresponded to one experimental unit, creating a total of 24 explants per genotype per treatment.

\section{Data recording and statistical analysis}

The variables evaluated were: number of microtubers/plantlet (NM), average fresh weight of microtubers/plantlet (WM), and average diameter of microtubers/plantlet (DM). Data were recorded for four months after starting the assay and analysis of variance and orthogonal contrasts over genotypes were computed using the statistical software Infostat (Di Rienzo et al., 2008).

\section{Results}

All of the treatments analyzed induced the formation of microtubers (Table 2). Differences in the number of microtubers (NM) between treatments depended on the genotype. There was no statistically significant effect of cytokinins BAP and $\mathrm{K}$ in the Atlantic variety, although the mean values of the attributes measured were between $15 \%$ and $69 \%$ higher than those of the control, respectively (Table 2). In the Alpha variety, the cytokinins yielded similar results, significantly increasing the number of microtubers $(\mathrm{p}=0.0040)$ from 3.2 units in the control to 5.6 and 6.5 for the BAP and kinetin treatments, respectively. The addition of ABA to cytokinins reduced the number of microtubers by 3.1 for the Alpha variety $(p=0.0002)$. Using cytokinins (no ABA),

Table 1.

Effect of different combinations and concentrations of cytokinins and a growth inhibitor on the microtuberization of Atlantic and Alpha potato genotypes

\begin{tabular}{ccc}
\hline & $\begin{array}{c}\text { Plant growth regulators }\left(\mathbf{m g ~ l}^{-1}\right) \\
\text { K }\end{array}$ & ABA \\
\hline 0.0 & 0.0 & 0.0 \\
6.5 & 0.0 & 0.0 \\
0.0 & 2.5 & 0.0 \\
6.5 & 0.0 & 1.0 \\
0.0 & 2.5 & 1.0 \\
\hline
\end{tabular}

Source: Authors' research. 
an average increase of 2.9 microtubers for this variety was obtained, which indicated that both cytokinins significantly increased the NM $(p \leq 0.01)$.

The effect of cytokinins on the weight of microtubers (WM) also depended on the genotype. In the case of the Atlantic genotype, an average of $181.4 \mathrm{mg}$ was obtained in the control, whereas cytokinins (without ABA) decreased the overall average to $106.5 \mathrm{mg}(\mathrm{p}=0.0095)$. In the case of the Alpha genotype, the average weight of microtubers in the control treatment was $120.6 \mathrm{mg}$. With the use of cytokinins (no ABA) an average increase of $53.5 \mathrm{mg}$ was obtained, but this was not significant ( $\mathrm{p}=$ 0.1885); both cytokinins yielded similar results. The addition of ABA to cytokinins caused an average weight reduction of 83.2 $\mathrm{mg}(\mathrm{p}=0.0131)$. For both genotypes, the interaction of ABA with kinetin appears to be more detrimental than that of BAP with kinetin (Table 2).
Differences in the diameters of microtubers (DM) is again a possible effect of regulators interacting with the genotype. The regulators did not have a significant effect on the Atlantic genotype, although there appears to be a strong negative effect of ABA when it interacts with $\mathrm{K}(31 \%)$, as compared to $\mathrm{BAP}+\mathrm{ABA}$, BAP and $\mathrm{K}$, where decreases in millimeters of $25 \%, 11 \%$ and $9 \%$, respectively, were recorded relative to the variables analyzed (Table 2). In/For Alpha, the result was similar to that obtained for WM, with cytokinins (without ABA) averages being higher than that of the control, although these differences were not significant $(\mathrm{p}=$ 0.2479 ), while the effect of ABA decreased the diameter by $1.5 \mathrm{~mm}(\mathrm{p}=0.0343)$.

\section{Discussion}

Our findings provide evidence for important effects of differences in genotypes on the inducibility and development of potato microtubers in terms of relative growth

Table 2.

Means \pm standard error for the number, weight, diameter, and orthogonal contrasts in the production of microtubers of potatoes (Solanum tuberosum L.) using three growth regulators

\begin{tabular}{lcccccc}
\hline \multicolumn{1}{c}{ Treatments } & NM & Atlantic & Potato cultivars & \multicolumn{2}{c}{ Alpha } \\
\multicolumn{1}{c}{ WM } & DM & NM & WM & DM \\
\hline Control & $2.6 \pm 0.8$ & $181.4 \pm 67.8$ & $5.5 \pm 1.2$ & $3.2 \pm 0.7$ & $120.6 \pm 7.2$ & $5.6 \pm 1.4$ \\
BAP & $4.4 \pm 1.0$ & $68.8 \pm 11.0$ & $4.9 \pm 0.2$ & $5.6 \pm 1.4$ & $176.5 \pm 34.1$ & $6.8 \pm 0.4$ \\
K & $3.0 \pm 0.5$ & $80.8 \pm 20.5$ & $5.0 \pm 0.3$ & $6.5 \pm 0.5$ & $171.7 \pm 46.1$ & $6.6 \pm 0.7$ \\
BAP + ABA & $3.2 \pm 0.5$ & $66.2 \pm 15.2$ & $4.1 \pm 0.3$ & $3.1 \pm 0.4$ & $106.1 \pm 3.3$ & $5.4 \pm 0.4$ \\
K + ABA & $3.0 \pm 0.7$ & $42.0 \pm 10.7$ & $3.8 \pm 0.4$ & $2.8 \pm 0.3$ & $75.6 \pm 10.3$ & $4.8 \pm 0.1$ \\
Contrasts & & & & & & \\
Cytokinins vs control & $1.1 \pm 0.9$ & $-106.5 \pm 39.2^{* *}$ & $0.6 \pm 0.8$ & $2.9 \pm 0.9^{* *}$ & $53.5 \pm 40.0$ & $1.0 \pm 0.8$ \\
BAP vs K & $0.8 \pm 0.8$ & $6.0 \pm 31.7$ & $0.1 \pm 0.7$ & $-0.2 \pm 0.7$ & $17.7 \pm 32.1$ & $0.4 \pm 0.7$ \\
With ABA vs Without ABA & $-0.6 \pm 0.8$ & $-20.7 \pm 31.7$ & $-0.9 \pm 0.7$ & $-3.1 \pm 0.8^{* *}$ & $-83.2 \pm 32.1^{*}$ & $-1.5 \pm 0.7^{*}$ \\
Cytokinins * ABA & $0.6 \pm 0.8$ & $-18.1 \pm 31.7$ & $-0.2 \pm 0.7$ & $-0.6 \pm 0.8$ & $-12.9 \pm 32.1$ & $-0.2 \pm 0.7$ \\
\hline
\end{tabular}

NM (number of microtubers); WM (weight of microtubers) (mg); DM (diameter of microtubers) (mm). ** Significance level $\leq 0.01$ or lower; $*$ Significance level $\leq 0.05$ or lower; orthogonal contrasts differences without an asterisk indicate non-significant values. $\mathrm{N}=24$. Source: Author's research. 
potential and productivity. Similar results were noted by Sharma et al., (2011a), who used a standard medium and culture conditions to show significant differences in the number of microtubers, performance, weight, size and dry matter content in six commercial potato cultivars, highlighting the importance of the genetic factor in the microtuberization process (Dobránszki et al., 2008).

These results confirmed the feasibility of forming microtubers in a growth regulator-free culture medium for both varieties (Table 2), which is in agreement with the results of previous studies (Aksenova et al., 2009; Donnelly et al., 2003; Romanov et al., 2000). Dobránszki et al. (2008) found higher microtuber yields without exogenous application of GR, when in vitro environmental factors such as light, temperature and mineral nutrition were modified. However, in our study the sensitivity of microtuberization without application of GR was higher in the Atlantic genotype, where the inclusion of cytokinins in the culture medium significantly decreased WM ( $\mathrm{p} \leq$ 0.01 ). These results might be attributed to experimental design, but our research was in accordance with the scientific literature dealing with microtuberization, commonly involving the use of a medium containing cytokinins and a growth retardant of gibberellin biosynthesis (Zhang et al., 2005b).

The differences in WM and DM when compared to the control could be explained by the work of Alexopoulos, Akoumianakis, and Passam (2006) who argued that the effects of cytokinins on increasing increase cell division and reducing tuber dormancy depend on the PA of the mother tubers. Villafranca et al., (1998) concluded that under in vitro conditions the PA of the mother tubers had a significant effect on responses in terms of microtuberization, confirming the importance of the PA throughout the process; however, in our study it was not possible to know the PA of the genotypes at the beginning of the assays. Other reasons that could explain these results include the endogenous level of GR, sucrose levels, and the formation of ethylene in an environment with low gas exchange.

In both genotypes the independent use of cytokinins increased microtuber production compared to using them in conjunction with ABA. In this regard, an increase of 53.5 $\mathrm{mg}$ in the WM of the Alpha genotype ( $\mathrm{p}=$ 0.1885 ) as a result of applying cytokinins (without ABA) was found, with a further beneficial effect when BAP was applied. Our results also confirm the findings of Sarkar $e t$ al., (2006), who reported a greater effect of BAP on in vitro potato tuber formation than that which was obtained with $\mathrm{K}$.

With regard to the independent effects of BAP, Lê (1999) observed significant differences for the variables fresh weight and microtuber size relative to $\mathrm{K}$ and the interaction of chlorocholine chloride (CCC) with BAP and K. Similarly, Gopal, Minocha, and Dhaliwal (1998) found that the addition of BAP to MS medium increased the yield and average weight of microtubers of 22 different genotypes, demonstrating that this cytokinin interferes with the innate ability of the genotypes to induce cell divisions at the beginning of microtuberization, probably due to imbalances in the endogenous levels of GR. The weight of microtubers in this study is similar to what was reported by Gopal et al., (1998), since values for this parameter decreased ( $p$ $\leq 0.01)$ in the Atlantic genotype and increased $53 \%$ in the Alpha genotype $(p \geq 0.05)$.

Furthermore, an increase in the number of microtubers in the Alpha variety due to the presence of BAP and $\mathrm{K}$ (without $\mathrm{ABA}$ ) was evident for both cytokinins $(\mathrm{p} \leq 0.01)$, 
although 16\% more microtubers were found in the presence of $\mathrm{K}$ in the culture medium, which is consistent with the results reported by Romanov et al., (2000) for the Désirée, Udacha, Nevskij, Lugovskoj and Andigenum varieties, and by Aksenova et al., (2005) for the Désirée variety and the transgenic variants Dara 5 and Dara 12. While these results can be explained by the work of Aksenova et al., (2009), who argued that the presence of kinetin in the culture medium caused a redistribution of endogenous cytokinins in the tissues in favor of underground organs and stimulated the formation of microtubers, others suggest a fundamental role of this cytokinin in cell division, metabolism of carbohydrates and other unrelated mechanisms that require the participation of endogenous cytokinins (Aksenova et al., 2005). The opposite was true in the Atlantic genotype, where cytokinin BAP yielded the highest number of microtubers ( $46 \%$ more than $\mathrm{K}$ ).

It seems that BAP plays a key role in microtuberization, since in this investigation the NM for the Atlantic variety, and the WM and DM for the Alpha variety, increased with respect to controls and $\mathrm{K}$, including the interaction $\mathrm{BAP}+\mathrm{ABA}$, which also increased the values NM, WM and DM of both varieties compared to $\mathrm{K}+\mathrm{ABA}$. These findings also confirm the results of Zhang et al., (2005a), who used combined treatments with BAP and other GR to obtain microtubers which did not occur using only auxin or auxin combined with gibberellic acid (GA).

Studies in the Arabidopsis model have shown that the addition of cytokinins to the media activates transmembrane histidine kinase receptors that signals in gene expression of cytokinin-sensitive genes via the action of nuclear type-B response regulators (RRs). Among the genes that are overexpressed, type-A response regulators attenuate the response to cytokinin, while cytokinin response factors (CRFs) are responsible for inducing expression of genes that are also targeted by type-B RRs. For example, cytokinin oxidases (CKXs) are involved in lowering cytokinin levels by cleavage in the cytosol and the apoplast; D3-type cyclins (CYCD3) are cell cycle regulators inducing constant mitotic activity and capable of inducing shoot formation in calli; SHY2 is a repressor of auxin target genes which, for example, downregulate the expression of the auxin efflux carrier PIN limiting auxin distribution; and IAA3 can repress the activity of transcription factors in the auxin response factor (ARF) family. Furthermore, gibberellin can repress the expression of type-B RRs (Brenner \& Schmülling, 2015; Chapman \& Estelle, 2009; Scofield, Dewitte, Nieuwland, \& Murray, 2013; Zürcher \& Müller, 2016).

In order to improve the number and size of tubers produced in vitro, it would be useful to carry out further testing, in which the independent effects and interactions of many factors are analyzed, including genotype, explants, photoperiod, temperature, sucrose concentration, $\gamma$ radiation (Li et al., 2005), concentration of ABA (Gopal et al., 2004; Xu et al., 1998), GA concentration (Xu et al., 1998), salt tolerance (Zhang et al., 2005a), carboxylic acid concentration (Sharma, Chanemougasoundharam, Sarkar, \& Pandey, 2004), genetic control of hormones through polygenic mappings (Ewing, Simko, Omer, \& Davies, 2004), cytokinin concentration, and the use of other growth retardants such as 2-chloroethyl trimethylammonium chloride (CCC), or Paclobutrazol (Donnelly et al., 2003). Even experimenting with temporary immersion systems should be considered in management programs to significantly increase fresh weight, diameter and length (Jiménez et al., 1999). 
The use of ABA as a growth inhibitor in this study did not favor the characteristics analyzed in both genotypes. However, this adverse effect was more evident in the Alpha genotype, where the incorporation of ABA significantly reduced WM, DM and $\mathrm{NM}(\mathrm{p} \leq 0.05)$. Our findings thus confirm the adverse effect of the interaction of ABA with the genotype, which according to Gopal et al., (2004), reduces the number and yield of microtubers. Nonetheless, more studies are needed to clarify the contradictory results of ABA on tuber formation, since some investigations report that ABA stimulates tuberization while others report an adverse effect (Xu et al., 1998).

Another possible explanation of the adverse effect of ABA on tuber formation is the presence of a high endogenous level of GA in both varieties. This hormone is considered to be a dominant regulator in the tuberization process through the inhibition of tuber initiation and growth (Xu et al., 1998). It is probable that the ABA concentrations used in the Atlantic and Alpha varieties were not high enough to act as antagonists to GA for all the variables, even with the use of cytokinins, which are regarded as tuber-inducing factors. The findings of this research also suggest that sucrose level regulated tuber formation by influencing endogenous GA levels as a signal for tuber initiation, and as a nutritious substrate for tuber growth (Romanov et al., 2000; Xu et al., 1998).

ABA functions via the activation of protein kinases, such as SnRK2s, resulting in the phosphorylation of downstream proteins involved in transcriptional regulation and ion transport (Yoshida, Mogami, \& Yamaguchi-Shinozaki, 2015). Some of those proteins reside in the nucleus, such as transcription factors ABI5, ABI4, $\mathrm{ABI} 3$, and related $\mathrm{ABA}$ responsive element
(ABRE) binding factors (ABFs), that when activated bind to ABRE and mediate the ABA-induced activation or repression of gene expression (Raghavendra, Gonugunta, Christmann, \& Grill, 2010; Finkelstein, 2013). In addition, ABA-mediated responses can include epigenetic changes induced by enzymes, such as histone deacetylases, that affect gene expression by modifying DNA methylation patterns and remodeling the chromatin (Finkelstein, 2013).

The independent stimulatory effects of cytokinins and ABA mentioned in various other studies were not evident in our experiment when both types of GR were added to the culture media. For example, in both varieties the synergic effect was negative, except for the case of NM for the Atlantic genotype $(p \geq 0.05)$. For these reasons, the synergic effect on microtuberization is still a controversial issue. In fact, the molecular crosstalk mechanisms between ABA and other phytohormone signaling pathways are not well understood (Raghavendra et al., 2010), and the proteins involved in ABA transcriptional regulation may also play a role in regulating responses to other phytohormones, sugars, and salt (Finkelstein, 2013).

The variability of results due to the interaction between genotypes and particular conditions of the culture medium indicates the need to develop genotype-specific protocols to improve the effectiveness of potato tissue culture systems (Gopal, Chamail, \& Sarkar, 2002; Gopal et al., 1998; Gopal, 2001; Sharma et al., 2011a,b).

\section{Conclusions}

In summary, the results obtained in this research indicate that it is possible to induce and develop microtubers in the Atlantic and Alpha varieties using only MS medium 
(1962) under diffuse light conditions and a $16 \mathrm{~h}$ /day photoperiod, without the addition of GR such as BAP or K and ABA at the concentrations studied. In this regard, the clearest results of testing were achieved for the Atlantic variety, where the values obtained for WM and DM decreased compared to the control treatment (without GR), while the values of NM did not. The independent action of the cytokinins BAP and $\mathrm{K}$ in potato microtuberization increased the NM, WM and $\mathrm{DM}$ in the Alpha genotype, while the combination of ABA and cytokinins in the doses used significantly decreased the values of all variables analyzed. Associating tuber ontogeny with a single factor is not justified, and it is necessary to optimize genotype-specific protocols to improve techniques for microtuber production as a source of genetic and phytosanitary seed quality.

\section{Acknowledgements}

The authors are grateful to the Plant Breeding Program at the 'Escuela de Ciencias Agrarias' at the 'Universidad Nacional' for financial support to conduct this research.

\section{References}

Abelenda, J. A., Navarro, C., \& Prat, S. (2011). From the model to the crop: genes controlling tuber formation in potato. Current Opinion in Biotechnology, 22(2), 287-292. https://doi. org/10.1016/j.copbio.2010.11.013

Aksenova, N. P., Konstantinova, T. N., Golyanovskaya, S. A., Sergeeva, L. I., \& Romanov, G. A. (2012). Hormonal regulation of tuber formation in potato plants. Russian Journal of Plant Physiology, 59(4), 451-466. https:// doi.org/10.1134/S1021443712040024

Aksenova, N. P., Konstantinova, T. N., Lozhnikova, V. N., Golyanovskaya, S. A., Gukasyan, I. A., Gatz, C., \& Romanov, G. A. (2005). Photoperiodic and Hormonal Control of Tuberization in Potato Plants Transformed with the PHYB Gene from Arabidopsis. Russian Journal of Plant Physiology, 52(5), 623-628. https:// doi.org/10.1007/s11183-005-0092-8

Aksenova, N. P., Konstantinova, T. N., Lozhnikova, V. N., Golyanovskaya, S. A., \& Sergeeva, L. I. (2009). Interaction between day length and phytohormones in the control of potato tuberization in the in vitro culture. Russian Journal of Plant Physiology, 56(4), 454-461. https:// doi.org/10.1134/S1021443709040037

Al-safadi, B., Ayyoubi, Z., \& Jawdat, D. (2000). The effect of gamma irradiation on potato microtuber production in vitro. Plant Cell, Tissue and Organ Culture, 61(3), 183-187. https:// doi.org/10.1023/A:1006477224536

Alexopoulos, A. A., Akoumianakis, K. A., \& Passam, H. C. (2006). Effect of plant growth regulators on the tuberisation and physiological age of potato (Solanum tuberosum L.) tubers grown from true potato seed. Canadian Journal of Plant Science, 86(4), 1217-1225. https://doi.org/10.4141/P05-227

Brenner, W. G., \& Schmülling, T. (2015). Summarizing and exploring data of a decade of cytokinin-related transcriptomics. Frontiers in Plant Science, 6 (January), 1-13. https://doi. org/10.3389/fpls.2015.00029

Chapman, E. J., \& Estelle, M. (2009). Cytokinin and auxin intersection in root meristems. Genome Biology, 10(2), 210. https://doi.org/10.1186/ gb-2009-10-2-210

Coleman, W. K., \& Coleman, S. E. (2000). Modification of potato microtuber dormancy during induction and growth in vitro or ex vitro. American Journal of Potato Research, 77(2), 103-110. https://doi.org/10.1007/ BF02853737

Coleman, W. K., Donnelly, D. J., \& Coleman, S. E. (2001). Potato microtubers as research tools: A review. American Journal of Potato Research, 78(1), 47-55. https://doi.org/10.1007/ BF02874824

Dobránszki, J., Magyar-Tábori, K., \& Hudák, I. (2008). In vitro Tuberization in Hormone-Free Systems on Solidified Medium and Dormancy of Potato Microtubers. Fruit, Vegetable and Cereal Science and Biotechnology, 2(1), 82-94.

Donnelly, D. J., Coleman, W. K., \& Coleman, S. E. (2003). Potato microtuber production and 
performance: A review. American Journal of Potato Research, 80(2), 103-115. https://doi. org/10.1007/BF02870209

Ewing, E. E., Simko, I., Omer, E. A., \& Davies, P. J. (2004). Polygene mapping as a tool to study the physiology of potato tuberization and dormancy. American Journal of Potato Research, 81(4), 281-289. https://doi. org/10.1007/BF02871770

Finkelstein, R. (2013). Abscisic acid synthesis and response. The Arabidopsis Book, e0166. https://doi.org/10.1199/tab.0166

Gopal, J. (2001). In vitro and in vivo genetic parameters and character associations in potato. Euphytica, 118(2), 145-151. https://doi. org/10.1023/A:1004062900701

Gopal, J., Chamail, A., \& Sarkar, D. (2002). Slowgrowth in vitro conservation of potato germplasm at normal propagation temperature. Potato Research, 45(2-4), 203-213. https:// doi.org/10.1007/BF02736115

Gopal, J., Chamail, A., \& Sarkar, D. (2004). In vitro production of microtubers for conservation of potato germplasm: effect of genotype, abscisic acid, and sucrose. In vitro Cellular \& Developmental Biology. Plant., 40(5), 485-490. https://doi.org/10.1079/IVP2004540

Gopal, J., Minocha, J. L., \& Dhaliwal, H. S. (1998). Microtuberization in potato (Solanum tuberosum L.). Plant Cell Reports, 17(10), 794-798. https://doi.org/10.1007/s002990050485

Jiménez, E., Pérez, N., de Feria, M., Barbón, R., Capote, A., Chávez, M., ... Pérez, J. C. (1999). Improved production of potato microtubers using a temporary immersion system. Plant Cell, Tissue and Organ Culture, 59(1), 19-23. https://doi.org/10.1023/A:1006312029055

Kawakami, J., Iwama, K., Jitsuyama, Y., \& Zheng, X. (2004). Effect of cultivar maturity period on the growth and yield of potato plants grown from microtubers and conventional seed tubers. American Journal of Potato Research, 81(5), 327-333. https://doi.org/10.1007/ BF02870178

Kefi, S., Pavlista, A. D., Meagher, M. M., \& Read, P. E. (2000). Short communication invertase activity as affected by cytokinin-like compounds during potato tuberization in vitro. American Journal of Potato Research, 77(1), 57-61. https://doi.org/10.1007/BF02853662

Lê, C. L. (1999). In vitro microtuberization: an evaluation of culture conditions for the production of virus-free seed potatoes. Potato Research, 42(3-4), 489-498. https://doi.org/10.1007/ BF02358165

Li, H. Z., Zhou, W. J., Zhang, Z. J., Gu, H. H., Takeuchi, Y., \& Yoneyama, K. (2005). Effect of $\gamma$-radiation on development, yield and quality of microtubers in vitro in Solanum tuberosum L. Biologia Plantarum, 49(4), 625-628. https://doi.org/10.1007/s10535-005-0062-1

López-Delgado, H. A., Sánchez-Rojo, S., Mora-Herrera, M. E., \& Martínez-Gutierrez, R. (2012). Micro-Tuberization as a Long Term Effect of Hydrogen Peroxide on Potato Plants. American Journal of Potato Research, 89(3), 240-244. https://doi.org/10.1007/ s12230-011-9219-y

Macháčková, I., Konstantinova, T. N., Sergeeva, L. I., Lozhnikova, V. N., Golyanovskaya, S. A., Dudko, N. D., ... Aksenova, N. P. (1998). Photoperiodic control of growth, development and phytohormone balance in Solanum tuberosum. Physiologia Plantarum, 102(2), 272-278. https://doi. org/10.1034/j.1399-3054.1998.1020215.x

Motallebi-Azar, A., Kazemiani, S., \& Yarmohamadi, F. (2013). Effect of sugar/osmotica levels on in vitro microtuberization of potato (Solanum tuberosum L.). Russian Agricultural Sciences, 39(2), 112-116. https://doi.org/10.3103/ S1068367413020146

Murashige, T., \& Skoog, F. (1962). A Revised Medium for Rapid Growth and Bio Assays with Tobacco Tissue Cultures. Physiologia Plantarum, 15, 473-497. https://doi. org/10.1111/j.1399-3054.1962.tb08052.x

Park, S. W., Jeon, J. H., Kim, H. S., Hong, S. J., Aswath, C., \& Joung, H. (2009). The effect of size and quality of potato microtubers on quality of seed potatoes in the cultivar "Superior." Scientia Horticulturae, 120(1), 127-129. https://doi.org/10.1016/j.scienta.2008.09.004

Raghavendra, A. S., Gonugunta, V. K., Christmann, A., \& Grill, E. (2010). ABA perception and signalling. Trends in Plant Science, 15(7), 395-401. https://doi.org/10.1016/j. tplants.2010.04.006

Romanov, G. A., Aksenova, N. P., Konstantinova, T. N., Golyanovskaya, S. A., Kossmann, J., \& Willmitzer, L. (2000). Effect of indole-3-acetic acid and kinetin on tuberisation parameters of different cultivars and transgenic lines of potato in vitro. Plant Growth 
Regulation, 32(2-3), 245-251. https://doi. org/10.1023/A:1010771510526

Sarkar, D., Pandey, S. K., \& Sharma, S. (2006). Cytokinins antagonize the jasmonates action on the regulation of potato (Solanum tuberosum) tuber formation in vitro. Plant Cell, Tissue and Organ Culture, 87(3), 285-295. https:// doi.org/10.1007/s11240-006-9166-3

Scofield, S., Dewitte, W., Nieuwland, J., \& Murray, J. A. H. (2013). The Arabidopsis homeobox gene SHOOT MERISTEMLESS has cellular and meristem-organisational roles with differential requirements for cytokinin and CYCD3 activity. Plant Journal, 75(1), 53-66. https:// doi.org/10.1111/tpj.12198

Shan, J., Song, W., Zhou, J., Wang, X., Xie, C., Gao, X., ... Liu, J. (2013). Transcriptome analysis reveals novel genes potentially involved in photoperiodic tuberization in potato. Genomics, 102(4), 388-396. https://doi. org/10.1016/j.ygeno.2013.07.001

Sharma, A. K., Venkatasalam, E. P., \& Singh, R. K. (2011). Micro-tuber production behaviour of some commercially important potato (Solanum tuberosum) cultivars. Indian Journal of Agricultural Sciences, 81(11), 1008-1013.

Sharma, S., Chanemougasoundharam, A., Sarkar, D., \& Pandey, S. K. (2004). Carboxylic acids affect induction, development and quality of potato (Solanum tuberosum L.) microtubers grown in vitro from single-node explants. Plant Growth Regulation, 44(3), 219-229. https://doi.org/10.1007/s10725-004-5827-6

Sharma, S., Venkatasalam, E. P., Patial, R., Latawa, J., \& Singh, S. (2011). Influence of gelling agents and nodes on the growth of potato microplant. Potato Journal, 38(1), 41-46.

Villafranca, M. J., Veramendi, J., Sota, V., \& Mingo-Castel, A. M. (1998). Effect of physiological age of mother tuber and number of subcultures on in vitro tuberisation of potato (Solanum tuberosum L.). Plant Cell Reports, 17(10), 787-790. https://doi.org/10.1007/ s002990050483
Xu, X., van Lammeren, A., Vermeer, E., \& Vreugdenhil, D. (1998). The role of gibberellin, abscisic acid, and sucrose in the regulation of potato tuber formation in vitro. Plant Physiology, 117(2), 575-584. https://doi. org/10.1104/pp.117.2.575

Yoshida, T., Mogami, J., \& Yamaguchi-Shinozaki, K. (2015). Omics approaches toward defining the comprehensive abscisic acid signaling network in plants. Plant and Cell Physiology, 56(6), 1043-1052. https://doi.org/10.1093/ $\mathrm{pcp} / \mathrm{pcv} 060$

Yu, J. W., Choi, J.-S., Upadhyaya, C. P., Kwon, S. O., Gururani, M. A., Nookaraju, A., ... Park, S. W. (2012). Dynamic proteomic profile of potato tuber during its in vitro development. Plant Science, 195, 1-9. https://doi. org/10.1016/j.plantsci.2012.06.007

Zhang, Z. J., Li, H. Z., Zhou, W. J., Takeuchi, Y., \& Yoneyama, K. (2006). Effect of 5-aminolevulinic acid on development and salt tolerance of potato (Solanum tuberosum L.) microtubers in vitro. Plant Growth Regulation, 49(1), 27-34. https://doi.org/10.1007/ s10725-006-0011-9

Zhang, Z., Mao, B., Li, H., Zhou, W., Takeuchi, Y., \& Yoneyama, K. (2005). Effect of salinity on physiological characteristics, yield and quality of microtubers in vitro in potato. Acta Physiologiae Plantarum, 27(4), 481-489. https://doi.org/10.1007/s11738-005-0053-z

Zhang, Z., Zhou, W., \& Li, H. (2005). The role of GA, IAA and BAP in the regulation of in vitro shoot growth and microtuberization in potato. Acta Physiologiae Plantarum, 27(3), 363-369. https://doi.org/10.1007/ s11738-005-0013-7

Zürcher, E., \& Müller, B. (2016). Cytokinin synthesis, signaling, and function-advances and new insights. In International review of cell and molecular biology (Vol. 324, pp. 1-38). Academic Press. https://doi.org/10.1016/ bs.ircmb.2016.01.001

\section{(2) $\mathbb{D} \Theta \Theta$}

Effect of two cytokinins and a growth inhibitor on the in vitro tuberization of two genotypes of Solanum tuberosum L. cvs. Atlantic and Alpha (José Antonio García-García y otros.) by Revista Uniciencia under a Creative Commons Attribution-Noncommercial-NoDerivs 3.0 Unported license. 